\title{
THE POSSIBILITY OF USING TIMBER FROM PLANTATION FOREST TREATED WITH PLASTIC AND CCB FOR MARINE CONSTRUCTION
}

\author{
Mohammad Muslich ${ }^{1,2}$ and Nurwati Hadjib ${ }^{1}$
}

\begin{abstract}
Recently, timber estate or plantation forest plays an important role on wooden based industries. However, the plantation timber quality is relatively low. Some treatments have been developed to improve its low quality, such as preservation with CCB (Chromate Copper Boron) and impregnation with plastic compounds. This study is to compare the durability of timber treated with plastic and CCB, non-treated from plantation forest timber as well as from natural forest. The plantation timber studied were jeungjing (Paraserianthes falcataria), damar (Agathis sp.), pinus (Pinus merkusii), and rubberwood (Hevea brasilliensis). Non-treated timbers that usually used for marine construction were ulin (Eusideroxylon zwageri), jati/teak (Tectona grandis), laban (Vitex pubescens) and merbau (Instia bijuga). After 6 and 12 months, the results showed that CCB preserved timber were more durable than plastic impregnated timber and nontreated timber. Wood samples were mostly attacked by marine borer organisms from the family of Pholadidae and Teredinidae. The experiment results revealed the possibility of using those plantation forest timber species for marine construction purposes.
\end{abstract}

Keywords: Chromate Copper Boron, durability, marine wood

\section{INTRODUCTION}

Woods used for shipbuilding, pier poles and beach housing, usually suffer from marine borer attack. Two common organisms of marine borer are Mollusca and Crustacea. The molluscan borers are bivalves distantly related to clams and oysters, the most important of which are Teredo, Bankia and Martesia. Teredo and Bankia are collectively called "teredine borers", or more commonly "shipworms". Their appearance are similar. The bodies are soft, elongated, and worm-like (hence called shipworms). At the head end is a pair of roughly globular boring shells with a rasp or file-like roughening used for burrowing. As boring progresses, this roughening is continually changed. At the tail end are two hard-feather or oar-shaped structures called "pallets" which protect a pair of "siphon tube". The structures of the "pallets" help in the identification of species (Turner, 1966).

\footnotetext{
Forest Products Research and Development Center. Jalan. Gunung Batu No. 5, P.O. Box 182, Bogor 16610

2 Corresponding author. E-mail: mohammad_muslich@yahoo.co.id
} 
Martesia is the genus found in our coastal waters. It is a typical bivalve shell with the body enclosed within the shells. It resembles a clam in general appearance and is pear-shaped, the tail end being slender. The shell seldom exceeds 1.5 inches in length but may attain a diameter of 0.75 inch. As in the case of shipworms, the young Martesia is a free-swimming organism that enters the wood through a small entrance hole. The burrow is the size, shape, and length of the shell and is nearly always at right-angled to the surface, and so, usually across the grain of wood (Mata and Siriban, 1972).

The wood-boring crustaceans are equipped with several pair of jointed legs, and are distantly related to the crab and wood louse. The borers of economic importance in this class are Limnoria, Chelura, and Sphaeroma. Limnoria or so-called "griblle" causes more damage to timbers than any other crustacean. These crustaceans are most active between tidemarks. Small bores are made on the surface of the piling and when great numbers of them are present, the burrows are separated by very thin walls of wood that are easily eroded by the motion of the water or objects floating upon it (Turner, 1966).

Marine constructions usually use high quality woods such as ulin (Eusideroxylon zwageri T.et B.), laban (Vitex pubescens Vahl.), teak (Tectona grandis L.f.), and merbau (Intsia bijuga O.Ktze.). The demand of such high quality wood tends to increase, while its supply is limited. To meet this need for marine construction wood with high quality has possibility to used plantationforest or timber-estate woods as substitute. The advantage of timber estate wood is to reduce exploitation on the natural forest, and for economic regional aspect, it would absorb employment. Jeungjing, pine, damar and rubberwood are fast growing plantation-forest species that are planted in Indonesia, having durability class V against marine borers (Muslich and Sumarni, 2005). They are not resistant against marine borer's attack. The application of preservation or chemical modification can improve the wood durability.

\section{MATERIALS AND METHODS}

The woods used for this study were jeungjing (Paraserianthes falcataria Niel.), damar (Agathis sp.), pinus (Pinus merkusii Jungh. et de Vries), rubberwood (Hevea brasilliensis), teak (Tectona grandis L.f.), merbau (Instia biyuga O.Ktze.), laban (Vitex pubescens, Vahl.) and ulin (Eusideroxylon zwageri T.et B.).

Test samples measuring $2.5 \mathrm{~cm} \times 5 \mathrm{~cm} \times 30 \mathrm{~cm}$ were prepared from the timber estate-wood species as mentioned above and teak, merbau, laban and ulin as comparison. Some of the samples (i.e. jeungjing, damar, pinus, and rubberwood) were treated with chromated copper boron (CCB) at 150 psi for 2 hours using full-cell process. The rest of those samples (i.e. jeungjing, damar, 
pinus, and rubberwood) was polymerized with methyl metacrylate (MMA), and then irradiated with gamma ${ }^{60} \mathrm{Co}$ at a rate of $40 \mathrm{kGy}$..

The test on marine borer attack was conducted in the waters of Rambut Island. The procedure for observation were as follows:

1. Each timber estate species was differentiated in 3 groups based on three durations or periods of marine borer attacks i.e. 3 months, 6 months, and 12 months.

2. At the end of observation periods, inspection on marine borer attacks was carried out by splitting up the samples.

3. Attack intensity could be determined using classification on wood resistance to marine borers (Muslich and Sumarni, 2005).

4. Kinds of attacking marine borers organisms could be identified using the marine borer classification by Turner (1971).

\section{RESULTS AND DISCUSSION}

The experiment revealed that there were different intensities of marine borer attacked depending on the duration of sample exposure to sea waters. Most of the untreated samples were severely attacked by the marine borers after 3-month exposure, particularly jeungjing, damar, pinus, and rubberwood. Light attack on control wood species was frequently found on merbau, teak, and laban after 6 months, while ulin was resistant for 12 months (Figure 1 and Table 1).

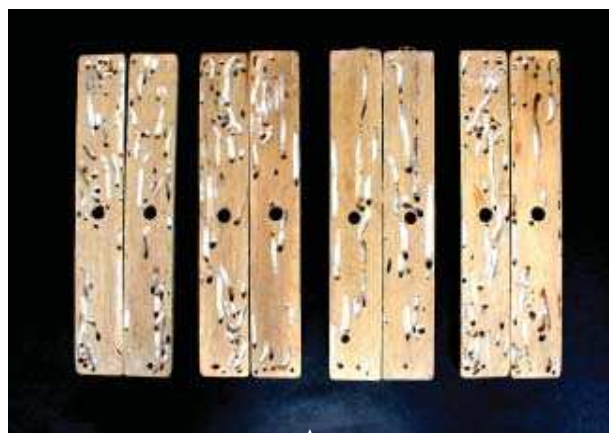

a b

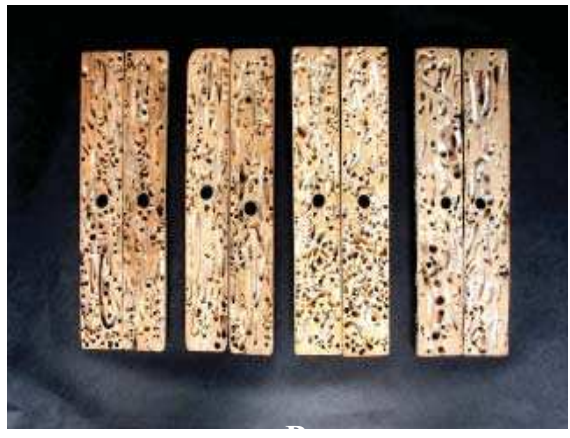

a b d

Figure 1. Intensity of marine borer infestation on untreated wood species after three months (A) and six months (B) exposure in the sea. Remarks: a. jeungjing, b. damar, c. pinus, d. rubberwood 
Table 1. The intensity of marine borer infestation on test wood pieces

\begin{tabular}{|c|c|c|c|c|c|c|c|c|}
\hline \multirow[b]{2}{*}{ No. } & \multirow{2}{*}{$\begin{array}{l}\text { Wood } \\
\text { species }\end{array}$} & \multirow{2}{*}{$\begin{array}{l}\text { Specific } \\
\text { gravity }\end{array}$} & \multirow{2}{*}{$\begin{array}{c}\text { Kinds of } \\
\text { Treatment }\end{array}$} & \multicolumn{3}{|c|}{ Attack intensity (\%) after } & \multicolumn{2}{|c|}{ Borer species } \\
\hline & & & & $\begin{array}{c}3 \\
\text { months }\end{array}$ & $\begin{array}{c}6 \\
\text { months }\end{array}$ & $\begin{array}{c}12 \\
\text { months }\end{array}$ & Pholad & Teredin \\
\hline 1. & Jeungjing & 0.42 & Control & 68 & 85 & $\mathrm{x}$ & ++ & +++ \\
\hline 2. & Damar & 0.45 & Control & 65 & 85 & $\mathrm{x}$ & ++ & +++ \\
\hline 3. & Pinus & 0.55 & Control & 63 & 90 & $\mathrm{x}$ & ++ & +++ \\
\hline 4. & Rubberwood & 0.61 & Control & 63 & 90 & $\mathrm{x}$ & ++ & +++ \\
\hline 5. & Teak & 0.64 & Control & 15 & 31 & 65 & ++ & + \\
\hline 6. & Merbau & 0.84 & Control & 20 & 40 & 85 & ++ & ++ \\
\hline 7. & Laban & 0.88 & Control & 5 & 28 & 60 & ++ & - \\
\hline 8. & Ulin & 1.04 & Control & 0 & 0 & 0 & - & - \\
\hline 9. & Jeungjing & 0.81 & MMA & 8 & 35 & 45 & ++ & + \\
\hline 10. & Damar & 0.74 & MMA & 5 & 33 & 40 & ++ & + \\
\hline 11. & Pinus & 0.97 & MMA & 5 & 32 & 40 & ++ & + \\
\hline 12. & Rubberwood & 0,91 & MMA & 9 & 35 & 45 & ++ & + \\
\hline 13. & Jeungjing & 0.53 & $\mathrm{CCB}$ & 0 & 0 & 0 & - & - \\
\hline 14. & Damar & 0.49 & CCB & 0 & 0 & 0 & - & - \\
\hline 15. & Pinus & 0.62 & $\mathrm{CCB}$ & 0 & 0 & 0 & - & - \\
\hline 16. & Rubberwood & 0.69 & CCB & 0 & 0 & 0 & - & - \\
\hline
\end{tabular}

Remarks : $\mathrm{MMA}=$ methyl methacrylate; $\mathrm{CCB}=$ chromated copper boron; $\mathrm{x}=$ completely destroyed; - = none; $+=$ slight $++=$ moderate; $+++=$ heavy

Polymer loading of pine was $162.2 \%$, rubberwood $44.66 \%$, jeungjing $46.3 \%$ and $51.7 \%$ dammar. The difference of polymer loading on each wood species was influence by its wood structure. The difference in wood resistance capacity against borer attacked is due to the differences in natural properties of wood species. Ulin, for example, has the highest specific gravity and contains extractive substances like "eusiderin". Silica content, wood strength or density and poisonous extractive substances could reduce or inhibit marine borer attack (Bianchi, 1933; Gongrijp, 1932; Southwell and Bultman, 1971). Silica could minimally reduce the marine borer attack intensity by $0.5 \%$. Bianchi (1933) carried out a study on wood resistance of several wood species against marine borers in Indonesia. Results of this study showed that kolaka wood (Parinari corymbosum Drig.) and teak wood that contained silica of 0.9 and $0.4 \%$ respectively, were highly resistant to marine borers. Silica content, wood strength or density and poisonous extractive substances were strongly influenced by wood growth process and growth pattern both of which were affected by environmental factors and heredity (Panshin and de Zeeuw, 1980). The fourth of wood species tested have low silica contain $(0.1-0.2 \%)$ and no poisonous extractives, so that all wood tested were susceptible to marine borers.

Results of observations showed that untreated jeungjing, damar, pinus, and rubberwood were attacked by the family Teredinidae. Identification results 
showed that those marine borers belong to species of Teredo bartschi Clapp. and Bankia cieba Clench. Teredinidae damages wood by using it as food resource, so that the attack of the test wood samples reached the interior part. Turner (1966) stated that the genus Teredo possessed celullase enzyme, so that the cellulose in the wood could be degraded into easily digested food. Teredinidae grows faster in wood species which contain high cellulose and low silica content, low hardness and exhibit soft texture.

Table 1 also shows that all MMA (plastic) polymerized woods (jeungjing, damar, pinus, and rubberwood) were resistant until 6 months. The increase in resistance capacity of all the plastic wood was caused by changes in wood chemical properties. Particularly, the changes in cellulose and lignin on modification due to wood polymerization with MMA. This condition is unfavorable for marine borers which require cellulose as their food. In addition, the hardness of plastic wood is greater than its compounding original wood (Figure 1, Table 2 and Table 3). This is one factor that supports an increase in wood resistance capacity against organism attack. This finding is reconfirmed by Clouston (1968) who stated that plastic wood usually exhibits higher physical and mechanical properties. Further, Kent et al. (1963) stated that plastic wood will be also more resistant against weather and the attack by destroying insects.

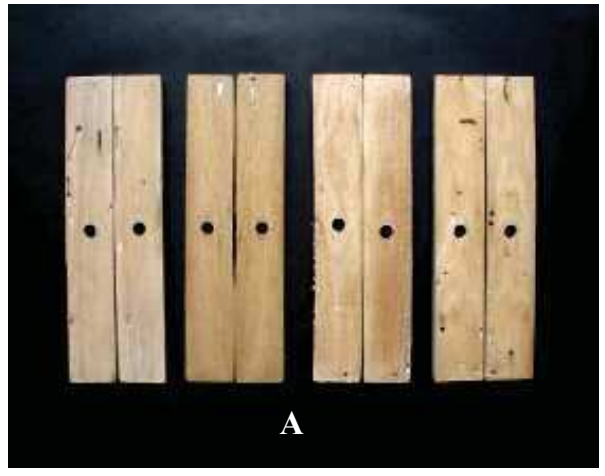

a b c d

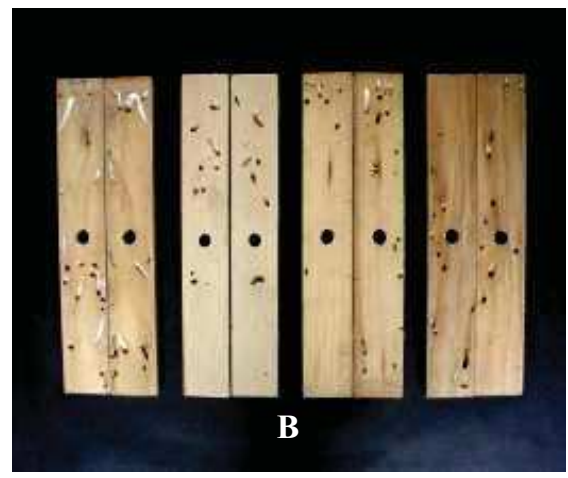

a b d

Figure 2. Intensity of marine borer infestation on wood plastic compounds after three months (A) and six months (B) exposure in the sea. Remarks: a. jeungjing, b. damar, c. pinus, d. rubberwood 
Table 2. Physical properties of wood polymerized with methyl metacrylate (MMA)

\begin{tabular}{lcccccccc}
\hline \multirow{2}{*}{ Wood species } & \multicolumn{2}{c}{$\begin{array}{c}\text { Specific gravity } \\
(\%)\end{array}$} & \multicolumn{2}{c}{$\begin{array}{c}\text { Moisture content } \\
(\%)\end{array}$} & $\begin{array}{c}\text { Water absorption } \\
(\%)\end{array}$ & \multicolumn{2}{c}{$\begin{array}{c}\text { Volumetric } \\
\text { shrinkage }(\%)\end{array}$} \\
\cline { 2 - 9 } & Control & MMA & Control & MMA & Control & MMA & Control & MMA \\
\hline Pinus & 0.44 & 0.97 & 30 & 8.87 & 96.66 & 13.77 & 7.63 & 3.27 \\
Rubberwood & 0.63 & 0.91 & 12.01 & 8.44 & 40.35 & 13.63 & 7.48 & 6.17 \\
Jeungjing & 0.42 & 0.81 & 46.94 & 6.55 & 34.12 & 6.66 & 6.69 & 3.75 \\
Damar & 0.45 & 0.74 & - & - & - & - & 8.55 & 7.41 \\
\hline
\end{tabular}

Table 3. Mechanical properties of wood polymerized with methyl metacrylate (MMA)

\begin{tabular}{lrrrrrrrr}
\hline Wood species & $\begin{array}{c}\text { Static bending } \\
\text { MOE }\left(\mathrm{kg} / \mathrm{cm}^{2}\right)\end{array}$ & $\begin{array}{c}\text { Static bending } \\
\text { MOR }\left(\mathrm{kg} / \mathrm{cm}^{2}\right)\end{array}$ & $\begin{array}{c}\text { Hardness }(\mathrm{kg} / \\
\left.\mathrm{cm}^{2}\right)\end{array}$ & \multicolumn{2}{c}{$\begin{array}{c}\text { Compresion } \\
\text { parallel } \\
\text { to grain }\left(\mathrm{kg} / \mathrm{cm}^{2}\right)\end{array}$} \\
\cline { 2 - 9 } & Control & MMA & Control & MMA & Control & MMA & Control & $\mathrm{MMA}$ \\
\hline Pinus & 76,153 & 172,847 & 598 & 1608 & 286 & 722.8 & 393.3 & 484.0 \\
Rubberwood & 117,912 & 125,470 & 1060 & 1350 & 471 & 942.5 & 488.9 & 486.5 \\
Jeungjing & 77,945 & 108,544 & 468 & 741 & 147 & 155.0 & 192.4 & 250.6 \\
Damar & 143,000 & 151,000 & 618 & 881 & 130 & 462.0 & 288.0 & 403.0 \\
\hline
\end{tabular}

This experiment also revealed that all plastic woods were attacked by the marine borer family of Pholadidae. The identification results showed that this borer belongs to species Martesia striata Linne. Pholadidae attacked wood using it as staying place, and the damage suffered by the wood only bring about shallow boring holes perpendicular to the wood surface and the hole size depends on the size of its cutting. Pholadidae in wood grew slower than Teredinidae, so that the wood attacked by Pholadidae had a relatively longer life. Similar attacks were also found on laban wood (Table 1 and Figure 2). This research result also showed that the wood which is resistant against the attack by Teredinidae is evidently not resistant against Pholadidae. Wilkinson (1979) stated that all wood species in waters which have a high Pholadidae population, would be attacked by this marine borer. Southwell and Bultman (1971) showed that Dicorynia paraensis and Crysophyllum cainito were woods which contain high silica content and therefore they were resistant to Teredinidae which damages marine construction materials and stone. 


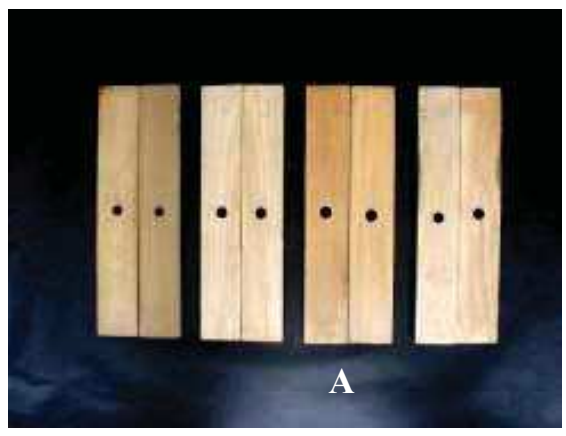

$\begin{array}{llll}a & b & c & d\end{array}$

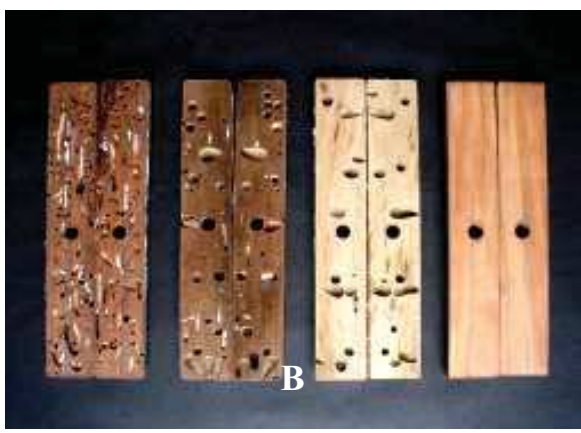

e $\quad f \quad g$

$\mathrm{h}$

Figure 3. Intensity of marine borer infestation on CCB-treated wood (A) and untreated wood (B) after twelve months exposure in the sea. Remarks: a. jeungjing, b. damar, c. pinus, d. rubberwood, e. merbau, f. teak, g. laban, h. ulin

Table 1 shows, that most of CCB-preserved specimens, were resistant until 12 months exposed in sea water. Wood species with low extractive or silica content were readily attacked by marine borers. However, those wood species were very permeable to liquid substances eventhough they were already dried. This means that they were easily impregnated with preservative solutions. It is fortunate that wood species with low extractive are permeable to liquids. Part of the timber is vulnerable is nevertheless easily preserved (Table 4).

Table 4. Retention $\left(\mathrm{kg} / \mathrm{m}^{3}\right)$ and penetration (\%) of Chromated Copper Boron (CCB) in particularwood species

\begin{tabular}{lccc}
\hline \multicolumn{1}{c}{ Wood species } & $\begin{array}{c}\text { Retention }(\mathrm{kg} / \\
\mathrm{m} 3)\end{array}$ & $\begin{array}{c}\text { Penetration } \\
(\%)\end{array}$ & Treatability class \\
\hline Pinus & 50.75 & 100 & A (easy) \\
Rubberwood & 30.25 & 70 & A (easy) \\
Jeungjing & 35.45 & 90 & A (easy) \\
Damar & 28.50 & 85 & A (easy) \\
\hline
\end{tabular}

The application of preservative treatment with high retention and deep penetration can reduce marine borer attack in jeungjing, damar, pinus, and rubberwood, eventhough these species have low extractive or silica content. This result is similar to or consistent with the experiment by Bianchi (1933) 
who proved that teruntum (Lumnitzera littorea Voight.) wood and bungur (Langerstromia specisa Pers.) wood were resistant to marine borer attack although they did not contain silica.

\section{CONCLUSION}

The untreated wood species of jeungjing, damar, pinus, and rubberwood were totally damaged at the third month of the experiment, while all the corresponding species treated wood plastic (MMA) survived until sixth months, and treated with CCB were resistant until 12 months. Light attack was frequently found in the control wood species, i.e. merbau, teak, and laban which were resistant for 6 months. Meanwhile, ulin was resistant for 12 months. The attacking marine borers were Martesia striata Linne. of Pholadidae family, Teredo bartschi Clapp., Dicyathifer manni Wright., and Bankia cieba Clench. of Teredinidae family. While all plastic woods survived until the sixth months, and all CCB preserved specimens resistant until 12 months.

\section{REFERENCES}

Bianchi, A.T.J. 1933. The resistance of some Netherlands East Indian timbers against the attack of shipworms (Teredo). Fifth Congress. Canada. pp. 3903 - 3906.

Clouston, J.G. 1968. Status and technology of polymer - containing fibrous materials. Proceedings. Panel Bangkok. IAEA, Vienna.

Gongrijp, J.W. 1932. Gegevends battrefende een onderzoek naar Nederlandesch Indische Houtsorten, Welke Tegen de Faal worm Bestand Zijn. Mededeelingen Van Het Bosbouwproefstation. No. 25 Bogor. pp 1- 99.

Kent, J.A., A.Wiston, W. Boyle and I. Updyke. 1963. Manufacture of woodplastic combination by use gamma radiation. Industrial User of Large Radiation Source. Vol. Proceedings of Conf. Salzburg, 1963. IAEA, Vienna.

Mata, P.G. and F.R. Siriban. 1972. Resistance of wood to marine borers. Technical Note, No.171. FORPRIDECOME, College, Laguna 3720. Manila.

Muslich, M. and G. Sumarni. 2005. Durability of 200 Indonesian wood species against marine borers. Journal of Forest Products Research, 23 (3): 163-168. Centre for Forest Products Research and Development, Bogor.

Panshin,A.J and C.D. Zeeuw. 1980. Text book of Wood Technology. $14^{\text {th }}$ ed Mc Graw-Hill Book Co. New York. 
Southwell, C.R. and J.D. Bultman. 1971. Marine borers resistance of untreated woods over long periods of immersion in tropical waters. Biotropica 3: 81-107. Naval Research Laboratory, Washington D.C.

Turner, R.D. 1966. A Survey and Illustrated Catalogue of Teredinidae. Museum of Comparative Zoology. Harvard University, Cambridge, Mass.

Turner, R.D. 1971. Identification on marine wood-boring mollusca. In: E.B.G. Jones and S.K. Eltringham (Eds.) Marine Borers, Fungi and Molding Organism of Wood., QECD, Paris. pp. 1-56.

Wilkinson, J.G. 1979. Industrial Timber Preservation. Associated Business Press, London. 